\title{
KREATIVITAS GURU MIN 16 ACEH BARAT DALAM MENINGKATKAN MINAT BELAJAR SISWA
}

\author{
Aja Julaiha ${ }^{1}$; Junias Zulfahmi ${ }^{2}$; Maya Agustina $^{3}$ \\ STAIN Teungku Dirundeng Meulaboh \\ ajajulaiha1998@gmail.com ; juniaszulfahmi@mail.com ; mayaagustn@staindirundeng.ac.id
}

\begin{abstract}
Abstrak.
Penelitian ini bertujuan mengetahui kreativitas guru bidang studi kelas V di MIN 16 Aceh Barat dalam meningkatkan minat belajar siswa dan mengetahui kendala-kendala yang dihadapi guru bidang studi kelas V di MIN 16 Aceh Barat dalam meningkatkan minat belajar siswa serta kendala-kendala yang dihadapi guru bidang studi kelas V di MIN 16 Aceh Barat dalam mengembangkan kreativitasnya. Jenis penelitian ini yaitu penelitian kualitatif. Teknik pengumpulan data yaitu observasi, wawancara dan dokumentasi. Sedangkan teknik analisis data yang digunakan dalam penelitian ini adalah analisis data kualitatif yang terdiri dari reduksi data, penyajian data, dan penarikan kesimpulan/verifikasi. Hasil penelitian menunjukkan bahwa meningkatkan minat belajar siswa melalui kreativitas guru dinilai belum maksimal, guru memang telah memanfaatkan media belajar dengan baik pada mata pelajaran tertentu, walaupun ada beberapa mata pelajaran lain yang belum menggunakan media yang mendukung pembelajaran. Akan tetapi guru mencoba menciptakan suasana belajar yang mendukung siswa agar semangat dalam belajar. Kendala yang dihadapi guru dalam meningkatkan minat belajar siswa yaitu guru masih belum maksimal dalam mengatur dan mengontrol siswa ketika sedang belajar. Selain itu, terbatasnya media dan sumber belajar milik sekolah yang dapat dimanfaatkan oleh guru serta singkatnya waktu yang dapat digunakan dalam proses pembelajaran.
\end{abstract}

Kata Kunci. Kreativitas, Peningkatan, Minat Belajar.

\begin{abstract}
This Studi aims to determine the creativity of class $V$ teachers in MIN 16 Aceh Barat in increasing student interest in learning and to find out the obstacles faced by teachers in developing their creativity. This type of research is qualitative research. Data collection techniques, namely observation, interviews and documentation. Meanwhile, the data analysis technique used in this research is qualitative data analysis consisting of data reduction, data presentation, and conclusion drawing/verification. The results showed that in increasing student interest in learning through teacher creativity, it was considered not optimal, the teacher had indeed utilized learning media well in certain subjects, although there were several other subjects that had not used media that supported learning. However the teacher tries to create a learning atmosphere that supports students so that they are enthusiastic in learning. The obstacle faced by teachersin increasing student interest in learning is that teacher are still not maximal in managing andcontrolling students while learning. In addition, there are limited school-owned media and learning resources that teachers can use and the short amount of time that can be used in the learning process.
\end{abstract}

Keywords. Creativity, Improvement, Interest In Learning.

Aja Julaiha | Junias Zulfahmi | Maya Agustina | Kreativitas Guru MIN 16 Aceh Barat dalam Meningkatkan Minat Belajar Siswa $\mid 148$ 


\section{PENDAHULUAN}

Salah satu keberhasilan dalam proses pembelajaran adalah adanya guru kreatif dalam segala hal yang berhubungan dengan pembelajaran baik di dalam kelas maupun di luar kelas. Guru harus kreatif dalam melaksanakan proses pembelajaran karena jika tidak kreatif pembelajaran kurang memuaskan (Alawiyah 2019; Pentury 2017).

Kreativitas guru adalah kemampuan seseorang atau pendidik yang ditandai dengan adanya kecenderungan untuk menciptakan atau kegiatan untuk melahirkan suatu konsep yang baru maupun mengembangkan hal-hal yang sudah ada di dalam konsep metode belajar mengajar yang mana untuk memberikan rangsangan kepada siswa agar siswa memiliki minat belajar sehingga dalam pembelajaran akan mempengaruhi prestasi belajar. Jadi guru yang kreatif sangat dibutuhkan karena dapat meningkatkan minat dan semangat belajar siswa sehingga siswa mempunyai minat untuk belajar(Rozikin, Amir, and Rohiat 2018; Syardiansah 2016; Sulistiowati 2014).

Terkait dengan peningkatan minat belajar ini, maka peran guru sebagai pembimbing belajar sangatlah penting. Guru yang mengajar kurang menarik, maka siswapun cenderung tidak tertarik, guru yang mengajar kurang serius, maka siswapun akan belajar tidak fokus dan sebagainya. Oleh karena itu, dalam konteks belajar di kelas, seorang guru atau pendidik lainnya perlu membangkitkan minat siswa agar tertarik terhadap materi pelajaran yang akan dipelajari (Aprijal, Alfian, and Syarifudin 2020; Arsyad and Salahuddin 2018).

Melihat dari realita yang ada, kreativitas guru sangat berperan penting dan sangat besar manfaatnya dalam pembinaan minat belajar siswa. Berdasarkan observasi awal yang diperoleh penulis di kelas V di MIN 16 Aceh Barat, diketahui bahwa beberapa guru dalam menyampaikan atau menyajikan materi pelajaran kurang menarik perhatian siswa dan pengunaan metode pembelajaran yang telah diterapkan masih bersifat konvensional, seperti metode ceramah. Jadi pembelajaran yang terjadi lebih berpusat pada guru.

Ternyata hal tersebut membuat siswa hanya mampu mendengar, mencatat, membuat tugas yang diberikan guru dan kurangnya antusias siswa dalam belajar. Kondisi tersebut cenderung menyebabkan siswa menjadi kurang bersemangat dalam belajar, bahkan ada beberapa siswa yang menyebabkan kegaduhan, mengganggu temannya yang sedang belajar, meskipun guru telah menegur siswa yang membuat kegaduhan, menyuruhnya untuk diam dan mengajukan pertanyaan kepada siswa yang menyebabkan kegaduhan dan yang mengganggu temannya, akan tetapi ketika guru mulai menjelaskan lagi pelajaran siswapun kembali berisik lagi seperti di awal, hal ini disebabkan karena siswa mulai merasa bosan dan kurang bersemangat dalam mengikuti pembelajaran, serta siswa pun cepat melupakan apa yang telah 
diberikan oleh guru. Sementara dalam pembelajaran yang paling dibutuhkan oleh siswa adalah semangat dalam mengikuti pelajaran, maka ini merupakan tuntutan bagi guru untuk menciptakan kreativitas mengajarnya.

Penulis memilih guru bidang studi kelas V di MIN 16 Aceh Barat sebagai objek penelitian karena dari beberapa kelas yang penulis amati, penulis merasa tertarik memilih kelas V karena minat belajar yang dimiliki siswa kelas V sangat kurang, dapat dilihat pada saat guru sedang mengajar, banyak siswa yang sering keluar masuk dengan alasan pergi ke kamar kecil, selain itu ada beberapa siswa yang menganggu temannya saat sedang belajar. Kemudian penulis juga tertarik untuk mengetahui sejauh mana kreativitas guru bidang studi kelas V di MIN 16 Aceh Barat yang berhubungan dengan penyusunan program pembelajaran dan pelaksanaan proses belajar mengajar yang mereka lakukan. Sehingga apabila guru telah mengembangkan kreativitasnya diharapkan minat belajar siswa dapat meningkat dan lebih baik lagi.

\section{METODE}

Jenis penelitian ini adalah penelitian lapangan yang dilakukan di MIN 16 Aceh Barat untuk mengetahui bentuk kreativitas guru bidang studi kelas V di MIN 16 Aceh Barat dalam proses belajar mengajar dan faktor-faktor yang mempengaruhi minat belajar siswa kelas $\mathrm{V}$ di MIN 16 Aceh Barat. Adapun yang menjadi data primer dalam penelitian ini yaitu guru dan kepala madrasah MIN 16 Aceh Barat, sedangkan data sekunder dalam penelitian ini berupa dokumentasi dan catatan yang berkenaan dengan permasalahan penelitian. Penelitian ini dilakukan di MIN 16 Aceh Barat yang terletak di Jln. Sisingamaraja Desa Lapang, Kec. Johan Pahlawan, Kab. Aceh Barat pada tahun 2020.

Dalam penelitian ini yang menjadi subjek penelitiannya adalah kepala madrasah dan 7 guru bidang studi kelas V. Adapun teknik pengumpulan data dalam penelitian ini dengan menggunakan observasi, wawancara, dan dokumentasi. Sedangkan teknik analisis data dengan menggunakan reduksi data, penyajian data dan verifikasi data/penarikan kesimpulan

\section{HASIL DAN PEMBAHASAN}

\section{Bentuk Kreativitas Guru Bidang Studi Kelas V Di MIN 16 Aceh Barat dalam Meningkatkan Minat Belajar Siswa.}

Peningkatan merupakan proses, cara, perbuatan meningkatkan (usaha, kegiatan, dsb).

Jadi peningkatan adalah lapisan dari sesuatu yang kemudian membentuk susunan, Aja Julaiha | Junias Zulfahmi | Maya Agustina | Kreativitas Guru MIN 16 Aceh Barat dalam Meningkatkan 
peningkatan berarti kemajuan, penambahan keterampilan dan kemampuan agar menjadi lebih baik. Peningkatan disebut juga suatu proses perubahan meningkat yaitu perubahan menjadi lebih baik.

Fokus pada penelitian ini yaitu untuk mengetahui bagaimana meningkatkan minat belajar siswa melalui kreativitas guru bidang studi kelas V di MIN 16 Aceh Barat. Untuk itu peneliti melakukan wawancara dengan kepala sekolah dan 7 guru bidang studi kelas V dalam menyusun program pengajaran, melaksanakan program pengajaran, dan menilai proses belajar mengajar yang telah dilaksanakan.

a. Kreativitas Guru dalam Menyusun Program Pengajaran.

Berdasarkan hasil wawancara dengan kepala sekolah guru bidang studi kelas V di MIN 16 Aceh Barat bahwa dalam memilih dan menetapkan tujuan pembelajaran, guru berpedoman pada silabus yang telah ditetapkan oleh sekolah. Dalam memilih dan mengembangkan bahan pembelajaran, guru mengikuti kebutuhan pelajaran yang akan diberikan kepada siswa. Dalam memilih dan mengembangkan strategi belajar mengajar untuk meningkatkan minat belajar siswa, guru bidang studi kelas $\mathrm{V}$ mencoba menggunakan strategi pembelajaran yang menarik (Pentury 2017).

Selanjutnya dalam memilih dan mengembangkan media yang sesuai pembelajaran, guru bidang studi kelas V kadang-kadang menggunakan media belajar dikarenakan keterbatasan sarana dan prasarana yang dimiiki sekolah. Sedangkan dalam memilih dan memanfaatkan sumber belajar, guru menggunakan sumber belajar yang tersedia di sekolah. Misalnya dalam pembelajaran PKN tentang menghargai keputusan bersama, guru mencoba mengembangkan bahan pembelajarannya seperti cara-cara mengambil keputusan bersama dan sikap mengambil keputusan bersama (Mubarak, Suyatna, and Ali Alamsyah Kusumadinata 2019).

Dalam memilih dan mengembangkan strategi belajar mengajar, guru menggunakan strategi pembelajaran yang menarik, seperti guru mengajak siswa untuk saling berdiskusi terkait dengan pelajaran yang sedang dipelajari. Sedangkan dalam memilih dan mengembangkan media yang sesuai dengan pembelajaran pembelajaran, guru menggunakan media belajar dengan memanfaatkan bahan-bahan yang ada disekitar, dikarenakan keterbatasan sarana dan prasarana yang dimiliki sekolah (Hidayati and Husna 2020). Dalam hal memilih dan memanfaatkan sumber belajar, guru menggunakan sumber belajar yang tersedia disekolah saja seperti lapangan olahraga, selebihnya siswa hanya belajar di dalam kelas (Julkifli 2019; Karjiyati 2016; Praptinasari, Santosa, and Probosari 2012).

b. Kreativitas Guru dalam Melaksanakan Program Pengajaran

Aja Julaiha | Junias Zulfahmi | Maya Agustina | Kreativitas Guru MIN 16 Aceh Barat dalam Meningkatkan Minat Belajar Siswa | 151 
Berdasarkan hasil wawancara dengan kepala madrasah guru bidang studi kelas V di MIN 16 Aceh Barat bahwa langkah-langkah yang dilakukan guru bidang studi kelas V dalam melaksanakan program pengajaran yaitu: dalam menciptakan suasana belajar mengajar yang tepat, biasanya guru mengajak siswa untuk melakukan permainan disela-sela proses pembelajaran agar siswa tidak merasa bosan, contohnya seperti permain bola salju, guru juga mengajak siswa untuk menonton video-video yang berkaitan dengan tema pembelajaran yang sedang dipelajari. Dalam mengatur ruangan belajar, kadang-kadang guru meminta siswa untuk membentuk kelompok. Selanjutnya dalam mengelola interaksi belajar mengajar, guru mengadakan belajar secara berkelompok agar siswa dapat berinteraksi dengan baik dan bekerja sama dengan temannya.

c. Tugas guru dalam menilai hasil belajar yang telah dilaksanakan

Berdasarkan hasil wawancara dengan kepala sekolah MIN 16 Aceh Barat bahwa langkah-langkah yang dilakukan guru bidang studi kelas $\mathrm{V}$ dalam menilai proses belajar yang telah dilaksanakan yaitu melakukan penilaian tentang proses belajar mengajar yang telah dilaksanakan siswa melalui ulangan harian, UTS dan UAS. Hal tersebut juga disampaikan oleh guru bidang studi kelas $\mathrm{V}$ bahwa langkah-langkah yang dilakukan guru dalam menilai proses belajar yang telah dilaksanakan siswa yaitu melakukan penilaian pembelajaran yang telah dilaksanakan melalui ulangan harian, UTS dan UAS.

\section{Kendala-Kendala yang Dihadapi Guru Bidang Studi Kelas V di MIN 16 Aceh Barat dalam Meningkatkan Minat Belajar Siswa.}

Berdasarkan hasil wawancara dengan kepala madrasah dan guru bidang studi kelas V di MIN 16 Aceh Barat, ada beberapa faktor yang menjadi kendala guru MIN 16 Aceh Barat dalam meningkatkan minat belajar siswa yaitu ketika dalam proses belajar mengajar guru masih belum maksimal dalam mengatur siswa dan mengontrol siswa ketika sedang melakukan proses pembelajaran, karena pada saat proses pembelajaran berlangsung banyak siswa yang suka bermain-main, sering izin ke kamar kecil, dan ada juga yang mengganggu temannya yang sedang belajar. Kurangnya pemahaman siswa tentang pelajaran yang diberikan oleh guru sehingga siswa banyak bermain ketika pembelajaran sedang berlangsung. Keinginan siswa untuk belajar dan kedisiplinan yang dimiliki siswa masih kurang. Serta peraturan-peraturan yang diberikan oleh guru tidak ditaati.

Jadi dapat kita ketahui bahwa kendala-kendala yag dihadapi guru bidang studi kelas V di MIN 16 Aceh Barat dalam meningkatkan minat belajar siswa yaitu guru masih belum maksimal dalam mengatur dan mengontrol siswa karena pemahaman siswa tentang pelajaran 
yang diberikan guru masih kurang.. Kurangnya keinginan untuk belajar dan kedisiplinan siswa dalam belajar karena masih sering bermain-main dan tidak mentaati peraturan yang diberikan oleh guru.

\section{Kendala-Kendala yang Dihadapi Guru Bidang Studi Kelas V di MIN 16 Aceh Barat dalam Mengembangkan Kreativitasnya.}

Berdasarkan hasil analisis data penelitian, ada beberapa faktor yang menjadi kendala guru bidang studi kelas V di MIN 16 Aceh Barat dalam mengembangkan kreativitasnya yaitu kurangnya sumber belajar yang dapat dimanfaatkan guru dan kurang tersedianya media belajar yang dapat digunakan oleh guru yang disediakan oleh pihak sekolah. Akan tetapi guru bidang studi kelas $\mathrm{V}$ tetap berusaha menciptakan media pembelajaran sendiri dengan memanfaatkan bahan-bahan yang ada disekitar dan bahan-bahan yang tersedia di internet serta memanfaatkan sumber belajar yang ada disekitar misalnya seperti memanfaatkan lapangan olahraga untuk kegiatan pembelajaran. Karena pihak sekolah tetap mendorong para guru untuk menyediakan dan menciptakan sendiri sumber dan media belajar untuk menunjang proses pembelajaran. Akan tetapi hendaknya pihak sekolah tetap terus berupaya melengkapi ketersediaan sumber dan media belajar yang dibutuhkan para guru dalam proses pembelajaran.

Jadi dapat kita kita ketahui bahwa kendala-kendala yang dihadapi guru bidang studi kelas V di MIN 16 Aceh Barat dalam mengembangkan kreativitasnya adalah kurangnya sumber belajar yang dapat dimanfaatkan guru serta kurang tersedianya media belajar yang dapat digunakan oleh guru.

\section{PENUTUP}

Bentuk kreativitas guru bidang studi kelas V di MIN 16 Aceh Barat dalam meningkatkan minat belajar siswa melalui kreativitas guru dinilai belum maksimal. Karena kurang tersedianya media pembelajaran yang dapat digunakan oleh guru serta sumber belajar yang dapat dimanfaatkan oleh guru, akan tetapi, guru mencoba menciptakan sendiri media dan sumber belajar dengan memanfaatkan bahan-bahan yang tersedia dilingkungan sekitar. Sedangkan dalam menetapkan tujuan pembelajaran, guru berpedoman pada silabus, dalam memilih dan mengembangkan bahan pembelajaran, guru mengikuti kebutuhan pelajaran yang akan diberikan kepada siswa, dalam memilih dan mengembangkan strategi belajar, guru mencoba menggunakan strategi pembelajaran yang menarik. Guru juga menciptakan suasana belajar yang mendukung dengan cara sering mengatur ruangan kelas dan mengajak siswa 
untuk melakukan permainan-permainan dan menonton video-video yang berkaitan dengan tema pembelajaran untuk menghilangkan rasa jenuh ketika belajar.

Selanjutnya kendala-kendala yang dihadapi guru bidang studi kelas V di MIN 16 Aceh Barat dalam meningkatkan minat belajar siswa yaitu guru masih belum maksimal dalam mengatur dan mengontrol siswa ketika sedang belajar karena pemahaman siswa tentang pelajaran yang diberikan masih kurang, kurangnya keinginan dan kedisiplinan siswa dalam belajar karena siswa masih suka bermain-main dan mengganggu temannya serta tidak mentaati peraturan yang telah diberikan oleh guru.

Kendala-kendala yang dihadapi guru bidang studi kelas V di MIN 16 Aceh Barat dalam mengembangkan kreativitasnya yaitu kurangnya sumber belajar yang dapat dimanfaatkan guru serta kurang tersedianya media belajar yang dapat digunakan oleh guru.

\section{DAFTAR PUSTAKA}

Alawiyah, Rizqa. 2019. "Pemanfaatan Ice Breaking Untuk Peningkatan Kemampuan Sosial Anak Autis ( Study Di Autis Center Kota Bengkulu ).” Institut Agama Islam Negeri Bengkulu.

Aprijal, Aprijal, Alfian Alfian, and Syarifudin Syarifudin. 2020. "Pengaruh Minat Belajar Siswa Terhadap Hasil Belajar Siswa Di Madrasah Ibtidaiyah Darussalam Sungai Salak Kecamatan Tempuling." MITRA PGMI: Jurnal Kependidikan MI 6 (1): 76-91. https://doi.org/10.46963/mpgmi.v6i1.125.

Arsyad, and Salahuddin. 2018. "Hubungan Kemampuan Membaca Al Qur' an Dan Minat Belajar Siswa Dengan Hasil Belajar Pendidikan Agama Islam (PAI)." EDUKASI: Jurnal Penelitian Pendidikan Agama Dan Keagamaan 16 (2): 179-90.

Hidayati, Tuti, and Faizatul Husna. 2020. "Learning English from Home during the Covid19: Investigating Learners' Experience for Online and Autonomous Learning." Langkawi: Journal of The Association for Arabic and English 6 (2): 202. https://doi.org/10.31332/lkw.v0i0.2223.

Julkifli, Muhammad. 2019. "Strategi Guru Mengelola Kelas Dalam Anak Lamban Belajar (Studi Kasus Di SDIT Al-Firdaus Banjarmasin).” Tesis. UIN Maulana Malik Ibrahim.

Karjiyati, Victoria. 2016. "Studi Komparasi Pembelajaran Tematik Menggunakan Model Inkuiri Dan Interaktif Untuk Pengembangan Sikap Peduli Lingkungan Dan Pelestarian Biodiversity Bagi Siswa Kelas IV 11 Kota Bengkulu." Jurnal PGSD: Jurnal Ilmiah Pendidikan Guru Sekolah Dasar, 9 (2): 236-42.

Mubarak, Fadel, Undang Suyatna, and Ali Alamsyah Kusumadinata. 2019. "Fungsi Media Sosial Grup WhatsApp Sebagai Media Komunikasi Guru Sekolah Alam Komunitas Fitrah Lebah.” Jurnal Komunikasi Dan Media 3 (2): 175-79. 
Pentury, Helda Jolanda. 2017. "Pengembangan Kreativitas Guru Dalam Pembelajaran Kreatif Pembelajaran Bahasa Inggris.” Jurnal Ilmu Kependidikan 4 (3): 265-72.

Praptinasari, Sintaria, Slamet Santosa, and Riezky Maya Probosari. 2012. "Pengaruh Penerapan Model Pembelajaran Assurance, Relevance, Interest, Assesment, and Satisfaction ( Arias ) Terhadap Hasil Belajar Biologi Siswa Kelas Xi Ipa Sma Al Islam 1 Surakarta." Pendidikan Biologi 4 (1): 78-88.

Rozikin, Slamet, Hermansyah Amir, and Salastri Rohiat. 2018. "Hubungan Minat Belajar Siswa Dengan Prestasi Belajar Siswa Pada Mata Pelajaran Kimia Di Sma Negeri 1 Tebat Karai Dan Sma Negeri 1 Kabupaten Kepahiang." Alotrop 2 (1): 78-81. https://doi.org/10.33369/atp.v2i1.4740.

Sulistiowati, Charolina. 2014. "Pengaruh Permainan Ice Breaking Terhadap Rasa Percaya Diri Dan Prestasi Belajar IPS Siswa Kelas IV Sekolah Dasar Negeri 2 Kemutug LOR.” Universitas Muhammadiyah Purwokerto.

Syardiansah. 2016. "Hubungan Motivasi Belajar Dan Minat Belajar Terhadap Prestasi Belajar Mahasiswa Mata Kuliah Pengaturan Manajemen.” Manajemen Dan Keuangan 5 (1): 243. 